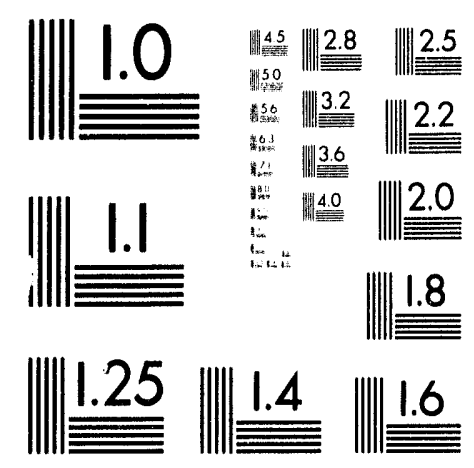



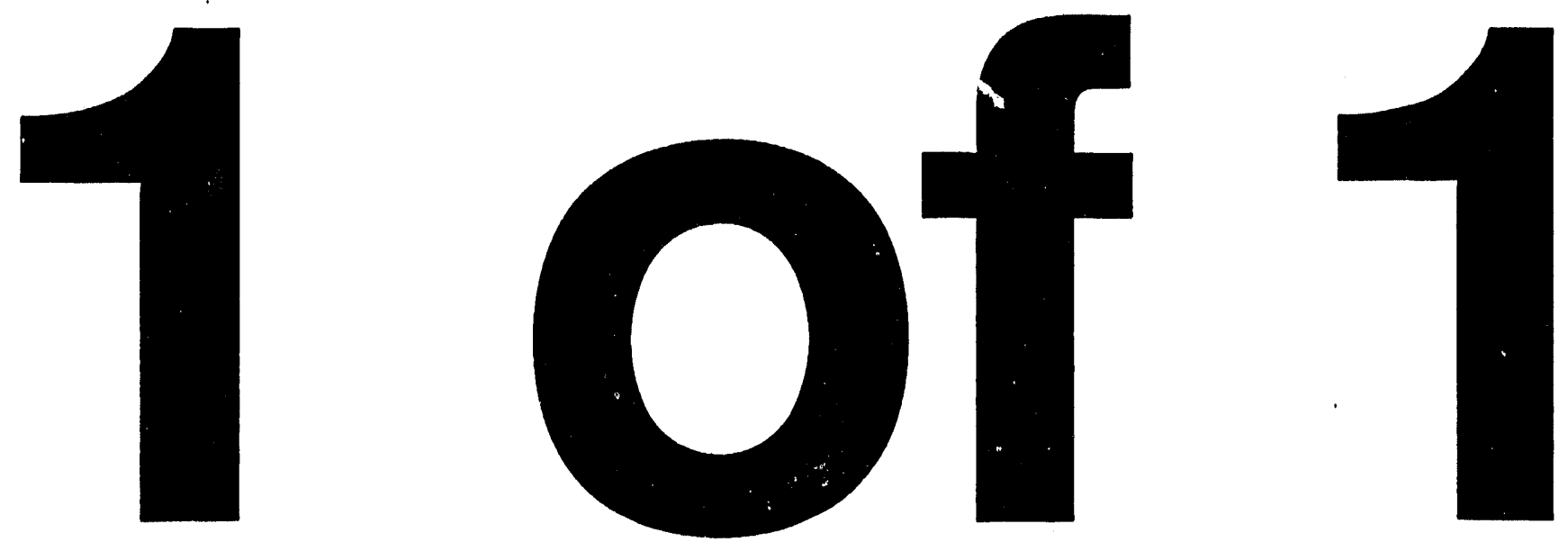


\title{
A REVIEW OF LITERATURE PERTAINING TO THE LEACHING AND SORPTION OF RADIONUCLIDES ASSOCIATED WITH NUCLEAR EXPLOSIVE MELT GLASSES
}

\author{
A Report by the Hydrologic Resources \\ Management Program of \\ Lawrence Livermore National Laboratory
}

David K. Smith

Nuclear Chemistry Division

May, 1993

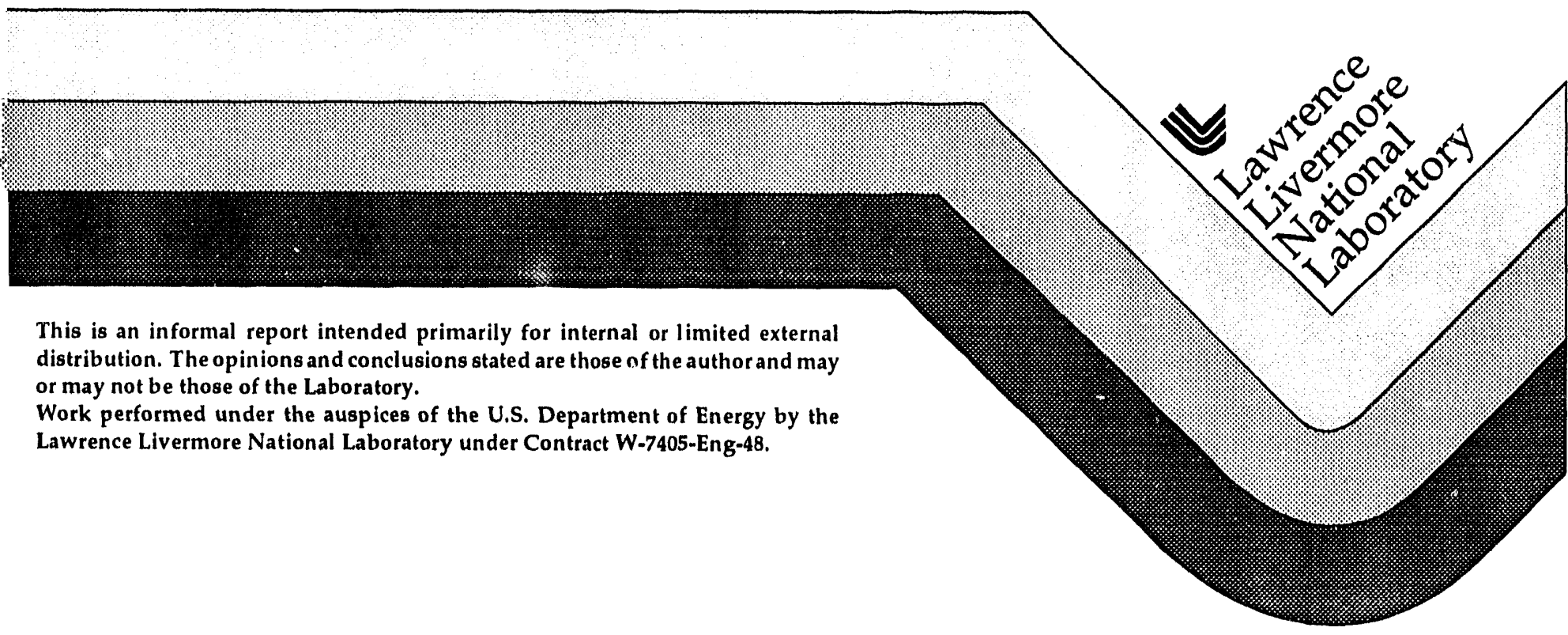




\section{DISCLAIMER}

This document was prepared as an account of work sponsored by an agency of the United States Government. Neither the United States Government nor the University of California nor any of their employees, makes any warranty, express or implied, or assumes any legal liability or responsibility for the accuracy, completeness, or usefulness of any information, apparatus, product, or process disclosed, or represents that its use would not infringe privately owned rights. Reference herein to any specific commercial products, process, or service by trade name, trademark, manufacturer, or otherwise, does not necessarily constitute or imply its endorsement, recommendation, or favoring by the United States Government or the University of California. The views and opinions of authors expressed herein do not necessarily state or reflect those of the United States Government or the University of California, and shall not be used for advertising or product endorsement purposes.

This report has been reproduced directly from the best available cops.

Available to DOE and DOE contractors from the Office of Scientific and Technical Information

P.O. Box 62, Oak Ridge, TN 37831

Prices a vailable from (615) 576.8401, FTS 626.8401

A vailable to the public from the

National Technical Information Service

U.S. Department of Commerce

5285 Port Royal Rd.,

Springfield, VA 22161 


\begin{abstract}
For the purposes of groundwater characterization, environmental remediation and health risk assessment, the mechanism and rate by which radionuclides bound within nuclear device melt glass are manifest in Nevada Test Site groundwaters must be known. Exchange between radionuclides and groundwater is dominated by the kinetics of leaching and the resultant sorption of derivative nuclides by minerals along the flow-path. In this context, a survey of the report literature has been conducted to review work related to these subjects.

This report provides a representative, although not exhaustive, summary of the literature; because of the specialized nature of nuclear melt glass, emphasis was given to the report literature available from Lawrence Livermore and Los Alamos National Laboratories, the Department of Energy and its predecessor agencies and pertinent contractors. Where data is corroborated in the refereed journal literature, those references are also included.

Before the risk to ground waters is estimated with any accuracy, recommendations for continued future work integrate systematic characterization of melt glass with leaching studies of these hoterogeneous matrices.
\end{abstract}




\section{INTRODUCTION}

This report contains a review of field, experimental and theoretical data pertaining to the leaching and sorption of radionuclides from nuclear device melt glass with emphasis on work published by the U.S. Department of Energy (DOE) and its contractors. The importance of leaching and sorption studies associated with the nation's nuclear testing program at the DOE's Nevada Test Site (NTS), Nye County, Nevada is vital to assessments of groundwater quality. The health risk associated with the migration of contaminated water is of concern in light of the increasing demands being placed on southern Nevada's water resource. Groundwater must be characterized relative to any radiologic component, and the maximum extent of radionuclide migration. Remediation and subsequent groundwater protection strategies further depend on accurate knowledge of radionuclide distribution and hydrology.

Integral to these objectives is an understanding of the movement of radionuclides in groundwater away from nuclear test centers. The radiological source at NTS comprises fission products, unburned fuel, activation products and tritium associated with atmospheric and subsurface nuclear events since testing commenced in January, 1951; since July, 1962 all tests have been executed underground and pose as potential point sources for ground water contamination. Testing has been confined to silicic volcanic rocks of Pahute Mesa (Areas 19 and 20) and volcaniclastic alluvium and silicic volcanics of Yucca Flat (Areas 1, 2, 3, 4, 6, 7, 9, 10 and 11) and Frenchman Flat (Area 5). Testing schedules have varied year-to-year; although the total number of tests remains classified, to-date approximately 1000 individual experiments have been fired at NTS. The matrix for the radiological component are heterogeneous melt glasses formed by temperatures in excess of $1 \times 10^{6} \mathrm{~K}$ and pressures greater than $7 \mathrm{Mbar}$ proximal to the working point (explosive center); surrounding the melt zone is a shock halo of intensely fractured and crushed rock with a radius 100 to 150 times that of the melt zone. The explosive shock wave vaporizes approximately 70 metric tons and melts another 700 metric tons of rock for every kiloton of yield (C. Smith, pers. comm.). Given the number of experiments conducted within the confines of NTS, the radiological source term is considerable. Exchange between radionuclides and groundwater is dominated by the kinetics of source-term leaching and the resultant sorption of derivative radionuclides by saturated or partially saturated minerals away from the explosive center.

Studies of the leaching of melt glasses and subsequent mineral sorption of radionuclides have steadily complemented the nuclear test program at NTS and most recently have been expanded to include thorough characterization of near-field radionuclide migration from a vitreous waste-form proposed for the high-level nuclear waste repository at Yucca Mountain, Nevada (Area 25, NTS). It should be emphasized that the two matrices, melt glass and high level nuclear waste glass, are compositionally and texturally unique. For this reason, other than a generic understanding of the stability, corrosion and alteration mechanisms of saturated or partially saturated glasses, direct comparisons are inappropriate. Studies of glass leaching and rudionuclide sorption by necessity incorporate compositional and textural aspects of glass formation related to the phenomenology of nuclear explosions. In this context, the subject of the leaching of melt glasses and sorption of radionuclides encompasses both the physics relating to the formation and distribution of the glass and the chemistry of the glass 
composition and its subsequent alteration.

The Hydrologic Resources Management Program (HRMP) has been charged with investigations of regional and local hydrology, transport processes and the radiologic source term at NTS. Attention has been focused on the near-field, those localized processes which occur close to a detonation cavity. Studies of the source term are vital because approximately $95 \%$ of the refractory radionuclides are confined to this region. Not much is known of radionuclide migration affecting the near-field, and leaching and sorption studies represent important and necessary first steps to conceptualize this mechanism.

This report presents a representative, although not exhaustive, review of the literature pertaining to leaching and sorption of radionuclides associated with nuclear melt glasses. Emphasis was given to glasses produced by nuclear detonations and the direction of the literature review followed this course. Because of the specialized nature of the subject, emphasis was given to the internal report literature available from Lawrence Livermore (LLNL) and Los Alamos (LANL) National Laboratories, the DOE and its predecessor agencies and pertinent contractors. Both the classified and unclassified literature were included, the former with an emphasis towards explosion phenomenology. Where data is corroborated in the refereed journal literature, those references are also included. Classified references are omitted pursuant to DOE and LLNL publication requirements. This report is organized in the following sections:

- Radionuclide Availability

- Explosion Phenomenology and Formation of Melt Glass

- $\quad$ Leaching of Radionuclides from Melt Glass by Groundwater

- Sorption and Desorption of Radionuclides

- Summary and Suggestions for Future Work

\section{RADIONUCLIDE AVAILABILITY}

A source term consists of radiologic and hydrologic components. Much of this topic is well developed by Borg et al. (1976). Radionuclide sources include fission and activation products, unburned fuel and tritium from the nuclear explosion; only those tests conducted below the water table are considered as potential point contamination sources. Considering a 1 kiloton all fission explosion, the activity of fission products decreases dramatically over ten years. From over twenty fission products measured at detonation, only nine are measurable $\left(>10^{-9} \mathrm{Ci}\right)$ ten years later and include ${ }^{99} \mathrm{Tc},{ }^{151} \mathrm{Sm},{ }^{137} \mathrm{Cs},{ }^{90} \mathrm{Sr},{ }^{85} \mathrm{Kr},{ }^{125} \mathrm{Sb},{ }^{147} \mathrm{Pm},{ }^{155} \mathrm{Eu},{ }^{106} \mathrm{Ru}$, ${ }^{144} \mathrm{Ce},{ }^{123} \mathrm{Sn}$ and ${ }^{127} \mathrm{Te}$; the ratio of activity from fission verses activation products is approximately 30 at detonation and rises to 220 after 100 years for both fusion and fission experiments. Estimates for tritium, unburned ${ }^{239} \mathrm{Pu}$, unburned ${ }^{235} \mathrm{U}$, fission products and rock activation products below or within one cavity radius of the water table at NTS (through 1975) are $1.3 \times 10^{8}, 4.8 \times 10^{4}, 1.6,1.8 \times 10^{8}$ and $5.6 \times 10^{6} \mathrm{Ci}$ respectively. Comprehensive estimates are presently being revised and will likely be available late this calender year (Wat Goishi, pers. communication). The hydrologic source term includes radionuclides potentially 
transferred to the groundwater.

During a nuclear explosion the device and the surrounding rock is either vaporized or crushed; the magnitude of these effects on the local geology varies with the yield of the explosion. Immediately after the explosion a cavity is created and all of the radioactive species exist as gasses; as the cavity ceases to grow, heat is transferred to the wall rock and cavity temperature and pressure drops. Melt which has formed on the cavity walls coalesces and flows to the floor of the cavity as a puddle entraining refractory radionuclides with higher boiling points (rare earths, alkaline earths, $\mathrm{Zr}$ and $\mathrm{Pu}$ ). Most of the refractory radionuclides will be trapped in the cooling melt; a small proportion will be incorporated with collapsed chimney rubble as splash or as fine droplets entrained with escaping cavity gases. Volatile species with lower boiling points (alkalis, $\mathrm{Ru}, \mathrm{U}, \mathrm{Sb}, \mathrm{Te}, \mathrm{I}$ ) will circulate up cracks in the rubble chimney. The final distribution of many longer-lived radionuclides will be determined by the partitioning of volatile shorter-lived radionuclide progenitors. Activation products will be concentrated around the working point and will be largely incorporated in the melt. The amount of radioactivity deposited will vary based on the individual experiment including the amount of fissile material, the fission/fusion ratio and the device yield. Uncertainties affect the determination of the fraction of radioactive products that are incorporated into the melt glass; of particular concern are longer lived fission products, such as ${ }^{90} \mathrm{Sr}$ and ${ }^{137} \mathrm{Cs}$, that have short-lived gaseous precursors $\left({ }^{90} \mathrm{Kr}\right.$ and $\left.{ }^{137} \mathrm{Xe}\right)$ which allow these species to migrate a considerable distance away from the burst before decaying to more refractory elements. Furthermore it is difficult to properly sample the heterogeneous glasses found at the chimney bottom and appraise the distribution of any radionuclide. Fractionation of radionuclides and the amount of glass produced to encapsulate these elements are estimated with uncertainty and vary considerably from experiment to experiment.

\section{EXPLOSION PHENOMENOLOGY AND FORMATION OF MELT GLASS}

To better understand the leaching and sorption process of melt glass, it is illustrative to understand how glass is generated in a nuclear explosion. Much of the following section is developed more thoroughly in the classified literature. Early time phenomenology consists of the tremendous energy release in the first $10^{-7}$ seconds after detonation. The device material is heated to several million degrees $\mathrm{K}$; a strong shock wave propagates away from ground zero vaporizing the surrounding rock. A cavity is formed; vapor pressures (depending on total yield) exceed $1 \mathrm{Mbar}$. The cavity continues to expand for $100 \mathrm{msec}$ until the cavity pressure drops to ambient hydrostatic overpressure. As the cavity grows, the main shock moves to the ground surface. Part of the shock wave is reflected back from the ground surface by refraction. The transmission of the shock wave causes either elastic or brittle failure in much of the material between the shot point and the ground surface. Hydrodynamic calculations indicate that the shock wave of the explosion vaporizes approximately 70 metric tons and melts another 700 metric tons of rock for every kiloton of explosive detonated for a variety of tests in differing geologic media (C. Smith, pers. comm.). 
Late time phenomenology commences after the cavity is stabilized and shock waves have dissipated. Rock debris and vapor condense leaving water vapor as the most important residual cavity gas; with continued cooling, the water vapor condenses. The transfer of heat to the surrounding rock creates a steep thermal gradient in rocks of the cavity wall which results in extensive cracking and flaking. Further cooling is promoted by spalled rock fragments which are incorporated within the condensing gas.

After minutes or hours the cavity can no longer support itself due to a reduction in the cavity pressure and the extensive cracking and fracturing in the cavity wall. The collapse propagates up towards the surface in a few seconds through material that has been extensively cracked by the explosion forming a rubble chimney. The infall of rubble quenches the remaining condensable cavity gas. Infall will continue to the surface if the cavity is unable to support a roof span approximately one cavity radius in diameter; chimney collapse will continue upwards to the surface and form a crater. The remaining incondensable gas, only slightly above atmospheric pressure, is trapped in the rubble and will reach the surface only by a tortuous path through the collapsed rock mass. The surface dust settles and the event concludes.

Zeolites incorporated in many of the tuffs at NTS change phase when exposed to the high pressure and water vapor generated during a nuclear explosion. Experiments by Morey (1958) using a powdered tuff which contained $70 \%$ modal heulandite $\left[(\mathrm{Ca}, \mathrm{Na})_{2.3} \mathrm{Al}_{3}(\mathrm{Al}, \mathrm{Si})_{2}\right.$ $\left.\mathrm{Si}_{13} \mathrm{O}_{36} \bullet 12 \mathrm{H}_{2} \mathrm{O}\right]$ and $10-29 \%$ total water indicate that when incrementally heated in a platinum bomb for 96 hours at $500^{\circ} \mathrm{C}$ with superheated steam injected at 6,500 psi, the heulandite is completely replaced by plagioclase. After 18 hours at a temperature of $650^{\circ} \mathrm{C}$ and $15,000 \mathrm{psi}$ with an final 2 hour increment to $30,000 \mathrm{psi}$, the plagioclase recrystallized to oligioclase, a plagioclase in the albite $\left[\mathrm{NaAlSi}_{3} \mathrm{O}_{8}\right]$ - anorthite $\left[\mathrm{CaAl}_{2} \mathrm{Si}_{2} \mathrm{O}_{8}\right]$ solid-solution series containing from $10-30 \%$ anorthite. Phenocrysts of quartz, potassium feldspar and plagioclase remained unaltered. Tracking phase changes is important to accurate characterization of the geologic media immediately surrounding detonation cavities; mineralogy along the hydrologic flow path will significantly affect the migration of radionuclides away from the explosive center.

Butkovich (1970) has studied the effect of water content in rocks on nuclear explosion effects. The water content of working point formations at NTS ranges from less than 1 to in excess of 25 weight percent. Molecularly bound water additionally depends on the constituent mineralogy. Larger cavities are formed from nuclear explosions in rocks of higher water content. The amount of water enhances cavity growth not only because the wet rock is weaker but, in addition, relative to the rock vapor, water vapor is noncondensable.

The September, 1957 Rainier event was the first contained underground explosion at NTS. Schwartz et al. (1984) investigated the texture, chemistry and composition of glasses recovered subsequent to the explosion. This event was fired at a depth of $274 \mathrm{~m}$ in a tunnel drift bored in the Oak Springs tuff of Rainier Mesa (Area 12). The yield was 1.7 kilotons. An excellent description of the Rainier event is provided by Wadman and Richards (1961); the reader should particularly note the unusual photographs made of the melt glass regions 
taken along the re-entry drift. The occurrence of Ranier melt glasses within breccias below the working point is described by Wilmarth (1959); the volume of glass within the breccia is between 0.5 and $3.0 \%$. Schwartz et al. (1984) recognized three glass types. The first is a dark glass which is highly radioactive and represents a bottom cavity puddle where melt coalesced and accumulated. The second variety is lighter in color, vesicular and low in radioactivity and is likely generated by super heat fusion of blocks incorporated into the melt puddle as the cavity expands. The third type of glass includes blebs, buttons and coatings which are both dense and highly radioactive. These glasses typically occur as fracture surfaces in fissures and along emplacement drift walls; this glass presumably represents the early condensate of gases composed of vaporized silicates. Elemental and textural analyses of the first of these glasses were obtained with the electron microprobe. Flow structures were documented in some of the glasses; however, flow was limited due to the viscosity of the anhydrous silica-rich melt. The glasses are enriched in silica $\left(\mathrm{SiO}_{2}\right.$ between $70-75$ weight percent) and alumina; $\mathrm{FeO}$ varies considerably and is more concentrated (up to 10 weight percent) in darker glasses than lighter equivalents. Schwartz et al. (1984) emphasize the chemical heterogeneities of the glass on scales as small as 20 to 40 microns. Variations, particularly in $\mathrm{Na}_{2} \mathrm{O}, \mathrm{K}_{2} \mathrm{O}$ and $\mathrm{FeO}$, mask any systematic variations in chemistry as a function of distance from the working point. Notably, the darker, silica poor glasses decrease in $\mathrm{FeO}$ away from the working point which suggests that these darker glasses may include remnants of the device debris. In summary Schwartz et al. (1984) note:

- $\quad$ glasses are dehydrated relative to their hydrated host tuffs

- glasses are extremely heterogeneous in major element composition

- chemical inhomogeneities occur on the scale of tens of microns

- dark, iron rich glasses occur closer to the working point

- there was no appreciable migration of major elements away from cavity

- $\quad$ shock melting is important in the production of these glasses

It should be emphasized that this study is the only published one of its kind to investigate the composition and texture of melt glasses.

Higgins (1959) states that for underground explosions at sufficient depth approximately $99 \%$ of the radiation associated with the nuclear explosion is contained by the phenomenology of the event. If the working point lithology is enriched in calcium and potassium, the resultant melt glass is considerably more susceptible to leaching; alternatively, if the working point is enriched in alumina and silica, the melt glass will be more insoluble. While a majority of the radionuclides would be trapped within the melt, cavity gases pose an additional problem particularly if the cavity collapses and the gases migrate. Of concern are the gases ${ }^{90} \mathrm{Kr}$ and ${ }^{137} \mathrm{Xe}$ which respectively decay to ${ }^{90} \mathrm{Sr}$ and ${ }^{137} \mathrm{Cs}$ with short (<3 minute) half-lives. If these gases were to escape, they would be adsorbed by fragment surfaces in the collapse zone; the probability that these radionuclides are contained hinges on the length of time the cavity stands before collapse. A measure of containment is the amount of $\mathrm{Sr}$ and $\mathrm{Cs}$ contained in the melt-glass. Since 65 to $80 \%$ of the fission products are incorporated in the melt, streaming of radioactive vapor is negligible. 
LLNL's Plowshare Program further addressed the total production of radioactivity from specific nuclear events at NTS and investigated the transport, deposition and redistribution of blast debris (Shore et al., 1969). While an emphasis was on empirical studies of cratering events, understanding the behavior of radionuclides for predictive purposes was a valuable product of the Plowshare Program. Particle studies of radionuclides produced from underground nuclear events indicate that partitioning of radionuclides follows a pattern that can be understood in terms of a three stage condensation process. An initial stage occurs in the underground cavity formed by the explosion. The refractory radionuclides $\left(\right.$ e.g. ${ }^{144} \mathrm{Ce}$, ${ }^{141} \mathrm{Ce}$ ), whose melting points are significantly above the melting temperature of the adjacent geologic media, are scavenged by the molten material that lines the cavity. The molten glass subsequently breaks up into particles that constitute slag. Both the radioisotopic composition and specific isotopic abundance in this fraction appear to be independent of particle size. Further condensation occurs during the passage of cavity gas through strongly shocked and crushed rubble surrounding the working point. During this stage, the radioisotopes of intermediate volatility (e.g. $\left.{ }^{132} \mathrm{Te},{ }^{137} \mathrm{Cs},{ }^{131} \mathrm{I}\right)$ complete their condensation. However, since this crushed material was not melted, these radionuclides are surface deposited rather than volume deposited. Radioactive particles are separated from the remaining radioactive gas as the gas ascends upwards through the rubble chimney. Final condensation occurs as residual gas ascends to the ground surface. The highly enriched volatile species (c.g. $\left.{ }^{106} \mathrm{Ru}\right)$ are significantly enriched in the soil fraction. Condensation occurs on non-molten particles and leads to the surface deposition of radionuclides. As such, the distribution of radionuclides is fractionated with heavier refractory nuclides being concentrated within the glass and lighter, volatile nuclides concentrated higher in the chimney. Studies of leaching and sorption must consider the vertical enrichment of source term nuclides within the stratigraphic section; as such, leaching (matrix effects) will be prevalent at depth and sorption-desorption (surface effects) will dominate at shallower intervals.

\section{LEACHING OF RADIONUCLIDES FROM MELT GLASS BY GROUNDWATER}

As melt glass becomes variably saturated with groundwater, radioactivity is transferred away from cavity and chimney sites. Borg et al. (1976) indicate this transfer is a two-stage process: 1) radionuclides are leached from the melt as soluble species and 2) the radionuclides in solution are sorbed onto surrounding chimney rubble or neighboring fractured rock. In the following section, the first stage is considered.

A variety of nuclear melt glass leaching studies are noted in the DOE and contractor report literature. Much of what is known about leaching and sorption of radionuclides from nuclear debris is derived from research which has complemented the nuclear test program over the past twenty-five years. Most of these investigations were published over ten years ago; the number of tests and access to device debris has diminished during the subsequent decade. Nonetheless, NTS groundwater characterization and remediation strategies demand that experimental work continue. Leaching of melt glass as a function of temperature warrants further investigation; thermal effects associated with underground nuclear explosions may be resident long after detonation and constrain glass solubility and leaching rate. 
Essington and Sharp (1968) and Essington (1971) conducted initial studies of glass leaching from the 1957 Rainier event described above; this work is also summarized by Borg et al. (1976). Glass from the Rainier explosion was used for three reasons: 1) the glass can be sampled readily by the extensive library of drill-cores and re-entry tunnels, 2) the tuff host rock approximates the composition and lithology of that found in Yucca Flat sediments and Pahute Mesa, and 3) the explosion is sufficiently old that short lived radionuclides are not present in any significant abundance. Some 700 metric tons of glass were produced by the explosion. Samples were collected from tunnel walls before being broken and sieved. A suite of several size fractions, from $<1$ to 16,000 microns, were subjected to static leaching in a synthetic groundwater prepared to approximate the composition of northern NTS spring waters. Experiments were run from 2 days to 4 years. The supernatant solution was removed, filtered through a $0.45 \mu \mathrm{m}$ filter, and radioassayed. Solids were measured for specific surface area by the Brunauer, Emmett and Teller (BET) gas adsorption method. As might be expected, particle sizes less than $500 \mu \mathrm{m}$ produce increased levels of alpha and beta radioactivities as well as cation and silica concentrations in the supernatant liquid. Relative to specific surface area, for size fractions $>1000 \mu \mathrm{m}$ the surface area measured pre- and postequilibration remains constant. The constant specific surface areas suggest that most of the measured surface area is not an external surface but an internal surface independent of particle size, that is, it is due to interconnected microfractures or vesicles. For the long term (4 year) test, only three radionuclides were present in sufficient quantity in the supernate to be measured: ${ }^{137} \mathrm{Cs}$, ${ }^{125} \mathrm{Sb}$ and ${ }^{90} \mathrm{Sr}$. Over the course of the experiment, ${ }^{90} \mathrm{Sr}$ levels remained between 0.1 and $0.2 \mathrm{dpm} / \mathrm{ml}$ which is indicative that once initial leaching of ${ }^{90} \mathrm{Sr}$ occurred subsequent sorption removed much of the leached strontium radionuclide. Leaching of ${ }^{125} \mathrm{Sb}$ appears to be slower than ${ }^{90} \mathrm{Sr}$. Release of ${ }^{125} \mathrm{Sb}$ continued to increase for 2.5 years until it leveled off. Under natural conditions $\mathrm{Sb}$ assumes an anionic form which is not as readily sorbed and which may account for its continued release. Release of ${ }^{137} \mathrm{Cs}$ by leaching of melt glass did not follow a simple trend. After approximately one year, the concentration of ${ }^{137} \mathrm{Cs}$ had increased approximately an order of magnitude from 0.1 to $1.5 \mathrm{dpm} / \mathrm{ml}$; after 2.5 years exposure, the concentration sharply decreased to approximately $0.05 \mathrm{dpm} / \mathrm{ml}$. This behavior was replicated with four separate samples. ${ }^{137} \mathrm{Cs}$ is known to be readily sorbed by clays and mineral surfaces, and the proposed explanation for this behavior is that as leaching progresses, chemical kinetics cause the reordering and reprecipitation of dissolved species into materials that have a higher affinity for cations such as ${ }^{137} \mathrm{Cs}$. Essington and Sharp (1968) conclude that: 1) groundwater in contact with melt glass may potentially dissolve contaminant radionuclides, 2) laboratory static leaching experiments using large pieces of glass are of utility for investigation of leaching of radionuclides short of sampling waters proximal to the blast center and 3) small pieces of glass, less than $250 \mu \mathrm{m}$, possess high specific surface area and chemical reactivity but do not represent water-glass interactions in the field.

Wolfsberg (1978) reports on static leaching experiments conducted with both highgraded and non-high-graded melt glass from tests beneath Yucca Flat and Pahute Mesa. Samples consisted of powders ground to less than 100 mesh as well as bulk samples 2 - 5 $\mathrm{mm}$ in maximum dimension. Groundwaters from NTS Well RNM-2S drilled into the alluvium of Frenchman Flat were used in the leaching experiments. Wolfsberg notes that the 
high-graded debris samples are enriched in ${ }^{99} \mathrm{Zr}$ relative to their non-high-grade equivalents. Samples were shaken in leaching solutions for up to 209 days. For the high-grade samples ${ }^{131}$ I leached the greatest in both ground and bulk samples. The difference in leaching between ground and bulk samples is not as much as would be expected by the difference in particle size if only surface area is important. Nuclides of $\mathrm{Mo}, \mathrm{Ru}, \mathrm{Sb}, \mathrm{Te}$ and $\mathrm{I}$ were leached faster during the first three days of the experimental run than later. Nuclides of I, Te, W and $\mathrm{Sb}$ have the highest leach rates; however, Wolfsberg cautions that the data should not be extrapolated to longer times. Calculating an average for high-grade, non-high-grade, ground and bulk melt debris samples from Yucca Flat and Pahute Mesa, leaching rates (in fraction leached per day) are arranged in decreasing order: ${ }^{131} \mathrm{I}$ (leaching rate: $0.9 \mathrm{E}^{-3}$ ) $>{ }^{129.132} \mathrm{Te}>$ ${ }^{181,188} \mathrm{~W}>{ }^{124,127} \mathrm{Sb}>{ }^{137} \mathrm{Cs}>{ }^{237} \mathrm{U}>{ }^{58,60} \mathrm{Co}>{ }^{103,106} \mathrm{Ru}>{ }^{182} \mathrm{Ta}>{ }^{140} \mathrm{Ba}>{ }^{141,144} \mathrm{Ce}>{ }^{54} \mathrm{Mn}>{ }^{88} \mathrm{Y}>$ ${ }^{95} \mathrm{Zr}>{ }^{239,240} \mathrm{Pu}$ (leaching rate: $3 \mathrm{E}^{\cdot 7}$ ). Wolfsberg does not consider how sorption will moderate leaching rates over geologic time.

Single pass flow-through leaching experiments of nuclear melt glass are summarized by Ramspott et al. (1979). The single pass flow system contrasts with the static leaching experiments described in that the solid sample is continuously exposed to fresh leaching solution that better simulates realistic hydrologic conditions underground. This is a nonequilibrium system in which the displacement from equilibrium can be varied by changing the flow rate of the solution. The samples were pieces of melt glass, chosen to be representative of high fission/fusion yields, that were ground and characterized by size distribution, physical appearance and specific surface area. Waters were real or simulated NTS ground water compositions. The experiment ran a total of 420 days with water sampling and radioanalysis after 1, 2, 3, 6, 11, 32, 38, 70, 120, 230 and 420 days. Ramspott et al. (1978) concludes 1) the leaching rate of nuclear melt glass by a single-pass leaching technique decreases with time in a manner similar to that observed for synthetic glasses in static experiments; 2) low flow rates give consistent statistically significant lower leach rates; 3 ) preliminary data indicate different leach rates for different isotopes, ${ }^{22} \mathrm{Na}$ being the fastest and ${ }^{95} \mathrm{Zr}$ being the slowest. Within these extremes, leaching rates can be arranged in decreasing order: ${ }^{124} \mathrm{Sb}>{ }^{137} \mathrm{Cs}>$ ${ }^{125} \mathrm{Sb}>{ }^{106} \mathrm{Ru}>{ }^{54} \mathrm{Mn}>{ }^{144} \mathrm{Ce}$. Examination of the solid phases suggests that the glass is inhomogeneous and is preferentially leached from areas susceptible to dissolution. These areas appear as active centers within the glass matrix and imply that the leaching of radionuclides is more complex than simple glass dissolution.

A single-pass flow-through leaching study of ground nuclear melt glass is reported by Failor et al. (1983). The leach test continually passed fresh leachate over the melt glass at $25^{\circ} \mathrm{C}$ for a total of 420 days. NTS Well 5B groundwater served as the leaching solution. The melt glass was chosen from events fired 0.5 to 1.5 years previous with high fission/fusion yields. Specific surface areas were measure on the solid samples. Flow rates were 185 $\mathrm{ml} /$ day for the first half of the experiment and $34 \mathrm{ml} /$ day for the remainder. Leachate solutions were collected after $1,2,3,6,11,32,38,70,120,230$ and 420 days and were analyzed by a $\mathrm{Ge}(\mathrm{Li})$ gamma spectroscopy. Results indicate that for most of the experiment the leach rate for ${ }^{22} \mathrm{Na},{ }^{54} \mathrm{Mn},{ }^{57} \mathrm{Co},{ }^{56} \mathrm{Co},{ }^{60} \mathrm{Co},{ }^{106} \mathrm{Ru},{ }^{124} \mathrm{Sb},{ }^{125} \mathrm{Sb},{ }^{137} \mathrm{Cs}$ and ${ }^{239} \mathrm{Pu}$ decreased regularly throughout the duration of the experiment. Except for ${ }^{95} \mathrm{Zr},{ }^{144} \mathrm{Ce}$ and ${ }^{154} \mathrm{Eu}$ there 
was no difference between the fast and slow flow rates. The measured leach rate ranged from a high of $1 \times 10^{2} \mathrm{~g}$-glass $/ \mathrm{m}^{2}$ day for ${ }^{22} \mathrm{Na}$ to a low of $1 \times 10^{-6} \mathrm{~g}$-glass $/ \mathrm{m}^{2}$ day for ${ }^{54} \mathrm{Mn}$. A majority of the glass leach rates were approximately $5 \times 10^{-4} \mathrm{~g}$-glass $/ \mathrm{m}^{2}$ day initially and decreased to $5 \times 10^{-6} \mathrm{~g}$-glass $/ \mathrm{m}^{2}$ day after 420 days of leaching. At 420 days, the leach rates were still decreasing and had not leveled off when the experiment was terminated. From the detected activities in leachate solutions, the percent of pre-leach activity dissociated from the melt glass during the experimental run was calculated. Only ${ }^{124} \mathrm{Sb}$ exceeded $3 \%$ of the activity originally present. The majority of samples released less than $1 \%$ of the pre-leach activity for a specific radionuclide. The percent activity released was similar for the both the fast (first half of run) and slow (second half of run) leach rates. Failor et al. (1983) concludes from the small percentage of activity leached from melt glass sampies that the potential for groundwater contamination due to the dissociation of melt debris is minimal. This is further emphasized by the differences in available reactive surface area in the ground glasses relative to the bulk glass surrounding the working point. ${ }^{239} \mathrm{Pu}$ had a higher than anticipated leaching rate $\left(10^{-4} \mathrm{~g}\right.$-glass $/ \mathrm{m}^{2}$ initial, $10^{-5} \mathrm{~g}$-glass $/ \mathrm{m}^{2}$ after 420 days); because the total amount release was small and the sorptive properties on alluvium and tuff are high, plutonium is relatively immobile.

\section{SUMMARY OF LEACHING OF RADIONUCLIDES FROM MELT GLASS}

- The leaching of melt glass is affected by glass composition. Calcium and potassium enriched glasses are more susceptible to leaching than those enriched in silica and alumina.

- Leaching rates increase with decreasing particle size. Smaller particles $(<250 \mu \mathrm{m})$ possess higher specific surface area and reactivity but do not mimic water-glass interaction in the field; leaching experiments using large $(>1000 \mu \mathrm{m})$ pieces of melt glass provide realistic leaching data short of sampling waters close to the working point. Internal surfaces, manifest as microfractures, offer much of the reaction surface.

- Absolute leaching rates are variable and range from $1 \times 10^{2}$ g-glass $/ \mathrm{m}^{2}$ for ${ }^{22} \mathrm{Na}$ to $1 \times 10^{-6} \mathrm{~g}$-glass $/ \mathrm{m}^{2}$ for ${ }^{54} \mathrm{Mn}$. Leach rates decrease through time from $5 \times 10^{-4} \mathrm{~g}$ glass $/ \mathrm{m}^{2}$ day initially to $5 \times 10^{-6}$ g-glass $/ \mathrm{m}^{2}$ day after $>400$ days reaction.

- Averages for the leaching rate (in fraction leached per day) of high-grade, nonhigh-grade, ground and bulk melt glass debris samples from Yucca Flat and Pahute Mesa are arranged in decreasing order: ${ }^{131} \mathrm{I}$ (leaching rate: $0.9 \mathrm{E}^{-3}$ ) $>{ }^{129,132} \mathrm{Te}>{ }^{181,188} \mathrm{~W}$ $>{ }^{124,127} \mathrm{Sb}>{ }^{137} \mathrm{Cs}>{ }^{237} \mathrm{U}>{ }^{58,60} \mathrm{Co}>{ }^{103,106} \mathrm{Ru}>{ }^{182} \mathrm{Ta}>{ }^{140} \mathrm{Ba}>{ }^{141,144} \mathrm{Ce}>{ }^{54} \mathrm{Mn}>{ }^{88} \mathrm{Y}>$ ${ }^{95} \mathrm{Zr}>{ }^{239,240} \mathrm{Pu}$ (leaching rate: $3 \mathrm{E}^{-7}$ ). 


\section{SORPTION AND DESORPTION OF RADIONUCLIDES}

The migration of radionuclides from nuclear melt glasses is the result of transport by groundwater. Interaction of radionuclides borne by groundwaters with the surrounding geologic media will significantly retard dispersal. Much of the geology of the NTS is composed of Miocene and younger ash-fall and ash-flow tuffs which contain highly sorptive minerals. Sorption comprises a variety of physiochemical processes including ion exchange, adsorption and chemisorption; determining whether sorption will occur requires knowledge of the likely flowpaths of ground water and the distribution of sorbing minerals along this path. The abundance and distribution of sorbing minerals and the long hydrologiz flow paths at NTS combine to minimize risk of radionuclide migration; however, for the purpose of predicting the behavior of radionuclides over the time-scales required to decay to safe levels, theoretical and quantitative understanding of the mechanisms of radionuclide transport and sorption-desorption is imperative.

Much of the following summary is provided by Borg et al. (1976). Sorption occurs either through charge imbalance or ion exchange; the former the result of subsidiary surface effects and the latter when an ion in solution is exchanged for an ion in a solid. The exchange reaction is reversible and, as such, retards but does not stop the flow of radioactive ions to ground water. The distribution coefficient, $K_{d}$, is a measure of ion exchange under equilibrium conditions and is conventionally defined as:

$$
K d=\frac{(\text { amount of } X \text { within solid }) /(\text { weight of solid })}{(\text { amount of } X \text { within liquid }) /(\text { volume of liquid })}
$$

where $\mathrm{X}$ is a specific radionuclide. $\mathrm{K}_{\mathrm{d}}$ values can be determined in the laboratory and values depend on the composition of the liquid phase, the composition and texture of the solid phase, temperature and related environmental parameters. Clays and zeolites, abundant in NTS tuffs and volcaniclastic sediments, display strong ion-exchange behavior. For much of the NTS, ion exchange is controlled by a small modal population of these strongly sorbing minerals. For clays, cation exchange capacities range from $0.02-0.10 \mathrm{meq} / \mathrm{gm}$ for kaolinites to $0.8-1.5$ $\mathrm{meq} / \mathrm{gm}$ for smectites; crystalline zeolites have cation exchange capacities of up to 3 to 4 $\mathrm{meq} / \mathrm{gm}$. It should be noted these values are representative and may vary relative to composition, temperature, crystallinity and particle size. Results for the sorption of $\mathrm{Sr}$ and $\mathrm{Cs}$ indicate for rocks and groundwaters of NTS, Cs has a higher sorption affinity than Sr. Relative to basalts and silicic volcanics off NTS, $K_{d}$ values are high for both NTS tuff and alluvium. A decrease in particle size will generally cause an increase in $\mathrm{K}_{\mathrm{d}}$. Changes in the $\mathrm{pH}$ of groundwaters are manifest in sorptive potential; $\mathrm{H}^{+}$may act simply as another competing cation or, if varied, may shift equilibrium conditions or react with the solid phase altering the chemical and physical nature of the exchange media. Consideration must be given to the effect of ionic size, electronegativity, oxidation and solubility on sorption behavior. Large ionic size and complexity (ability to form anions) dramatically attenuate sorbing capacity. 
Case Studies:

An early review of sorption associated with nuclear testing is provided by Knox (1968) who investigated the water quality of flooded nuclear craters under ine auspices of the Plowshare Program. He identifies the selected long-lived fission products of ${ }^{235} \mathrm{U}$ as ${ }^{106} \mathrm{Ru}$, ${ }^{144} \mathrm{Ce},{ }^{90} \mathrm{Sr}$ and ${ }^{137} \mathrm{Cs}$; these radionuclides move slowly with respect to the flow of ground water. A review of ion exchange experiments indicate that statistically determined distribution coefficients are adequate for predicting effluent histories of one dimension homogeneous media as well as complex media. As radionuclide concentration and flow rates increase, dilution and remediation strategies, beyond simple isolation, will be required to limit the release of radioisotopes to ground water. Knox suggests that ion exchange will slow the movement of these isotopes with respect to prevailing ground water velocities such that concentrations of these nuclides would be minimized.

Isherwood (1977) further emphasizes the role of sorption in moderating radionuclide migration. Isherwood defines the retardation factor $\left(\mathrm{K}_{\mathrm{f}}\right)$ as:

$$
K f=1+r K d
$$

where $K_{d}=$ distribution coefficient and

$$
r=\left(\frac{(1-\theta)}{\theta}\right) \rho
$$

where $\theta=$ effective porosity of the rock and $\rho=$ rock density. Although retardation is primarily defined as a function of the ion exchange distribution coefficient, retardation factors used in calculating transport represent combined effects of ion exchange and adsorption of charged colloidal species on silica surfaces. She identified 23 biologically significant radionuclides and divided them into three groups: 1) fission and activation products with no sorption, 2) fission products with sorption, 3) actinides and their daughter products. The distinction between fission products and actinide separates the $\alpha$ emitters from the $\beta$ and $\gamma$ emitters. The same retardation factors are applied to both intergranular and fracture flow; it is assumed equilibrium conditions exist between the water and rock to permit full ion exchange. For the Group 1 elements iodine and technetium, a zero $\mathrm{K}_{\mathrm{d}}$ is derived from theoretical and experimental evidence. Group 2 elements include ${ }^{90} \mathrm{Sr},{ }^{90} \mathrm{Y},{ }^{93} \mathrm{Zr},{ }^{93} \mathrm{Nb},{ }^{126} \mathrm{Sn},{ }^{134} \mathrm{Cs}$ and ${ }^{137} \mathrm{Cs}$. There is considerable range in the $\mathrm{K}_{\mathrm{d}}$ 's for $\mathrm{Sr}$ and $\mathrm{Cs}$ relative to different rock media; the "best" average of $\mathrm{K}_{f}$ for these elements is $10^{2}$. Group 3 elements include $\mathrm{Am}, \mathrm{Np}, \mathrm{Pu}$ and $\mathrm{Th}$. In some cases parent and daughter isotopes migrate at different velocities; for the theoretical case, decay isotopes are treated identically to their parents. For a pH range of 5 to 8 in natural water, the reported $K_{d}$ 's vary greatly. For example, the thorium distribution coefficient can range from 40 to $>10^{5}$. Using average distribution coefficients for these elements, a $K_{d}$ of 200 to 300 is a conservative estimate; the corresponding $K_{f}$ is approximately $10^{4}$. 
Literature values suggest that relative retardation factors are:

$$
\mathrm{Th} \geq \mathrm{Pu}>\mathrm{Am}>\mathrm{Np}>\mathrm{Ra}
$$

The actual differences in retardation factors will be a function of rock type, groundwater composition, flow type (intergranular versus fracture) and flow rate. For the purposes of modeling, Isherwood feels justified in treating these actinides as a group. Nonetheless, the fact that these are averages should be emphasized; $\mathrm{Pu}$ may have a retardation factor $>10^{7}$. Isherwood recommends that ion exchange and retardation studies be strengthened by evaluating how $\mathrm{K}_{\mathrm{d}}$ 's are measured - batch versus flow through measurements, evaluating the effect of $\mathrm{Eh}, \mathrm{pH}$, groundwater composition and rock type on radionuclide retardation and by study of the rates of ion exchange.

Wolfsberg (1978) reviewed experimental work on the sorption and desorption of radionuclides in alluvium. After radionuclides enter groundwater by leaching processes, the nuclide may sorb or desorb from solids during transport. Possible mechanisms include ion exchange, precipitation or other processes. Wolfsberg states that equilibrium may not be obtained between the liquid and solid phase during batch sorption experiments and advised caution when using the definition of distribution coefficient $\left(\mathrm{K}_{\mathrm{d}}\right)$ provided above. In his experiments the distribution of radioactivities is measured and the resulting value is called the distribution ratio, $R_{d}$, which is defined in the same way as $K_{d}$ but does not imply equilibrium. Batch sorption experiments were performed by shaking weighed quantities of a specified solid (crushed rock) particles, preequilibrated with ground water, with $20 \mathrm{ml}$ of spiked water for a given period of time at a constant temperature. At the end of the experiment, the aqueous phase was separated from the solid for analysis. Desorption experiments were performed by shaking the solids from the sorption experiments with $20 \mathrm{ml}$ of ground water; again, the aqueous phase was separated for analysis. The solids used in these experiments consisted of alluvium from Area 5 of NTS as well as bentonite. Area 5 NTS groundwaters were used as the fluid phase in these experiments. Wolfsberg (1978) concludes:

- $\quad$ Strontium equilibrates by sorption in three days, however the $K_{d}$ appears to be dependent on particle size and temperature. Sorption experiments with a 100 - 200 mesh size fraction exhibit $\mathrm{K}_{\mathrm{d}}$ 's of $239 \mathrm{ml} / \mathrm{g}$ at room temperature and $536 \mathrm{ml} / \mathrm{g}$ at $70^{\circ} \mathrm{C}$. For desorption at room temperature the value is $175 \mathrm{ml} / \mathrm{g}$. A value of 217 $\mathrm{ml} / \mathrm{g}$ is recommended as the equilibrium value for sorption-desorption for the $100-200$ mesh alluvial fraction at room temperature.

- Barium equilibrated in 12 to 24 days at room temperature and in 3 days at $70^{\circ} \mathrm{C}$. A $\mathrm{K}_{\mathrm{d}}$ value for the $100-200$ mesh alluvial fraction is $4400 \mathrm{ml} / \mathrm{g}$ at room temperature and $8750 \mathrm{ml} / \mathrm{g}$ at $70^{\circ} \mathrm{C}$.

- Cesium equilibrates after approximately 12 days at room temperature and in 3 days at $70^{\circ} \mathrm{C}$. For $100-200$ mesh alluvium, the $K_{d}$ is $8300 \mathrm{ml} / \mathrm{g}$ at room temperature and 6000 $\mathrm{ml} / \mathrm{g}$ at $70^{\circ} \mathrm{C}$. The recommended average value is $7700 \mathrm{ml} / \mathrm{g}$.

- Cobalt equilibrates after 14 days at $70^{\circ} \mathrm{C}$. For sorption the $K_{d}$ s are $13300 \mathrm{ml} / \mathrm{g}$ and $18000 \mathrm{ml} / \mathrm{g}$ at room temperature and $70^{\circ} \mathrm{C}$ respectively. For desorption, the $\mathrm{K}_{\mathrm{d}}$ is 
$28000 \mathrm{ml} / \mathrm{g}$ at room temperature.

- Yttrium, cerium and europium have measured $K_{d}$ 's that exceed $20000 \mathrm{ml} / \mathrm{g}$.

- Antimony has a range of distribution coefficients due to its complex chemistry. Sorption experiments yield $\mathrm{K}_{\mathrm{d}}$ 's of $6.0 \mathrm{ml} / \mathrm{g}$ and $12 \mathrm{ml} / \mathrm{g}$ at room temperature and $70^{\circ} \mathrm{C}$ respectively. The $K_{d}$ for desorption is much greater than for sorption, $65 \mathrm{ml} / \mathrm{g}$, assuming equilibrium was attained in 140 days.

- Uranium $K_{d}$ 's for sorption and desorption were 7 and $9 \mathrm{ml} / \mathrm{g}$ respectively. For deionized water, the $\mathrm{K}_{\mathrm{d}}$ for sorption is $60 \mathrm{ml} / \mathrm{g}$. The difference may be due to the higher carbonate concentration in the ground water leading to competition between the carbonate complexing and sorption of the uranyl ion.

- Iodine has a small sorption coefficient, $25 \mathrm{ml} / \mathrm{g}$; however the $\mathrm{K}_{\mathrm{d}}$ for desorption is 400 $900 \mathrm{ml} / \mathrm{g}$.

- Molybdenum $\mathrm{K}_{\mathrm{d}}$ is approximately $23 \mathrm{ml} / \mathrm{g}$.

- Niobium equilibrates after 3 weeks for sorption and somewhat longer time for desorption. The $\mathrm{K}_{\mathrm{d}}$ for sorption is $2700 \mathrm{ml} / \mathrm{g}$.

- Ruthenium $\mathrm{K}_{\mathrm{d}}$ is $1040 \mathrm{ml} / \mathrm{g}$ and equilibrates in 14 days. Desorption $\mathrm{K}_{\mathrm{d}}$ are larger at $2500 \mathrm{ml} / \mathrm{g}$.

In summary, Wolfsberg ranks distribution coefficients in increasing order: $\mathrm{Sb}<\mathrm{Sr}<\mathrm{U}(\mathrm{VI})<$ $\mathrm{I}<\mathrm{Ru}<\mathrm{Nb}<\mathrm{Ba}<\mathrm{Cs}<\mathrm{Co}<\mathrm{Y}<\mathrm{Ce}<\mathrm{Eu}$.

Batch sorption experiments conducted by MacLean et al. (1978) after the technique of Wolfsberg (1978) exhibit relative $\mathrm{R}_{d}$ 's as $\mathrm{Pu}>\mathrm{Cs}, \mathrm{Cs}>\mathrm{Sr}$ and $\mathrm{Sr}>\mathrm{Tc}$. This experiment involved an array of different geologic media (basalt, limestone, dolomite shale, granite, tuff) and groundwater types (brines and synthetic waters).

A variation on batch sorption experiments are reported by Treher and Raybold (1982) who passed a solution of radionuclides through columns of crushed tuff, granite and argillite to simulate the migration of radionuclides under flowing conditions. Because ion exchange, sorption, precipitation and mineral dissolution can retard radionuclide flow, studies employing columns have advantages over those using the batch process. Particulate transport can be studied. Migration rates can be directly observed by comparing the elution of a radionuclide with that of groundwater itself. Unfortunately gravity driven crushed rock flow-through column experiments are very time consuming and prohibitively long in duration. Experiments were conducted with gravity flow columns filled with crushed tuff, granite and argillite from NTS. Particle dimensions ranged from 38 to $500 \mu \mathrm{m}$ and were highly dependent on the lithology of the sample. Dilute bicarbonate groundwater from well J-13, NTS was eluted through the columns for several days to pack and pretreat the columns. The columns were then loaded with a spike solution of ${ }^{85} \mathrm{Sr},{ }^{137} \mathrm{Cs},{ }^{133} \mathrm{Ba},{ }^{95} \mathrm{Tc},{ }^{152} \mathrm{Eu}$ and ${ }^{141} \mathrm{Ce}$. Flow rates were 11 to $60 \mathrm{~m} /$ year. Samples were counted on a $\mathrm{Ge}(\mathrm{Li})$ detector. These experiments indicated the sorption ratios as measured by the elution of $\mathrm{Sr}, \mathrm{Cs}, \mathrm{Ba}$ were in agreement with batch measurements on washed fractions of these same rocks. When results of batch measurements containing finer grained samples (<38 microns) were compared with column data, column results were consistently lower. Because batch measurements are a convenient way to rapidly 
measure sorption on a large number of samples, and their relevance has been questioned, these results tend to validate batch experiments, at least for the larger particle size.

LANL's systematic laboratory studies of radionuclide migration are compiled by Erdal $(1979,1980)$. A portion of this work is also summarized by Vine et al. (1980). Data from batch experiments indicate that particle size has little effect on retardation over the range $500 \mu \mathrm{m}$ to $100 \mu \mathrm{m}$. Effects of groundwater composition were significant; essentially the more dilute the groundwater, relative to major cations and anions, the higher the sorption for Cs and $\mathrm{Ba}$ and the lower the sorption for Eu. Relative to the ionic strength of groundwater, sorption ratios varied over an order of magnitude. Rock composition also affects sorptive capacity; sorption ratios for $\mathrm{Sr}, \mathrm{Cs}, \mathrm{Ba}, \mathrm{Ce}$ and $\mathrm{Eu}$ are lowest for major phase $>20 \%$ quartz and feldspar ( \pm analcime), ratios are intermediate for major phase $>20 \%$ glass ( \pm clay) and ratios are highest for major phase zeolite (heulandite). Data for flow through crushed rock flow-through column experiments indicate than $R_{d}$ values are lower than those determined by batch experiments. A continuous pass, closed loop circulating experiment where radionuclides in solution were repeatedly exposed to crushed tuff eliminates "weathering" noted in batch experiments and a gradual increase in sorption ratios with time. $K_{d}$ 's from the circulating experiments are comparable with those from the crushed rock flow-through column experiments and lower than those determined from batch experiments. As such, except in cases where sorption coefficients are relativeiy low and ion-exchange exclusively removes radionuclides from solution, a simple relation between sorption (or retardation) coefficient and radionuclide velocities in groundwater may be insufficient to realistically characterize the migration of radionuclides.

Daniels (1981) and Wolfsberg et al. (1981) further review LANL's laboratory work on radionuclide migration. Much of the work reported here involves the studying the effects of variables which affect radionuclide sorption and desorption. Specifically, Daniels reports on batch sorption experiments in both air and a controlled atmosphere of nitrogen, $<0.2 \mathrm{ppm}$ oxygen and $<20 \mathrm{ppm}$ carbon dioxide for $\mathrm{Cs}, \mathrm{Sr}, \mathrm{Ba}, \mathrm{Ce}, \mathrm{Eu}, \mathrm{Tc}, \mathrm{U}, \mathrm{Pu}$ and $\mathrm{Am}$ on granite, argillite and tuff. For the granite and argillite, sorption ratios in the controlled atmosphere were higher for $\mathrm{Ce}, \mathrm{Eu}$ and $\mathrm{Tc}$ and lower for $\mathrm{U}, \mathrm{Pu}$ and $\mathrm{Am}$. $\mathrm{Sr}, \mathrm{Cs}$ and $\mathrm{Ba}$ were least affected. For the tuff, Tc, U, and Pu sorbed more strongly in the controlled atmosphere. A collateral study investigated the sorption of iodine on argillite. ${ }^{131} I$ shows a small but measurable $R_{d}$ for the argillite between 2 and $6 \mathrm{ml} / \mathrm{g}$. Values for alluvium and tuff and 20 and $0 \mathrm{ml} / \mathrm{g}$ respectively. Since radionuclide concentrations may be elevated proximal to the source, the dependence of the sorption ratio on concentration was investigated by batch experiments. When the solution/solid ratio was increased from 5:1 to $30: 1$ sorption of $\mathrm{Ba}, \mathrm{Ce}$ and Eu by tuff increased by a factor of 5; in contrast, sorption of $\mathrm{Sr}$ and $\mathrm{Cs}$ was unaffected. Most likely, these changes are driven by either precipitation and/or sorption. Confirming data presented by Vine et al. (1980) above, batch sorption experiments yield sorption ratios 2 to 3 times greater relative to crushed rock flow-through column experiments; variations in the sorption data depend on the sorbing element and sample mineralogy. Experimental results on sorption using solid tuff cores contained in a Teflon sleeve and pressurized (1000 psi) groundwaters showed a $\mathrm{Sr}$ sorption maximum at the core midsection which remained elevated 
throughout the remaining length of the core. $R_{d}$ values for $S r$ are approximately $20 \mathrm{ml} / \mathrm{g}$; lower than those determined from batch experiments. ${ }^{241} \mathrm{Am}$ remained in an aggregate form on external core surfaces and did not pass through the tuff. There is evidence to suggest that leakage occurred between the Teflon confining sleeve and the core surface which compromises direct comparisons with crushed rock flow-through column experiments

More recently, mineralogical control of sorption has been investigated particularly in the context of the proposed Yucca Mountain high-level nuclear waste repository. Meyer et al. (1991) report on measurements of $\mathrm{Sr}$ and $\mathrm{Cs}$ sorption by clinoptilolite and Calico Hills tuff from NTS. Their objective was to see if there was a correlation between sorption of Sr and Cs by the tuff and the clinoptilolite based on the tuffs zeolite content. If sorption was due exclusively to the $50 \%$ modal abundance of clinoptilolite, the ratio of sorption on the tuff to that on the clinoptilolite under similar experimental conditions should be equal to the weight percentage of clinoptilolite, in this case 0.5 . None of the other phases of the Calico Hills tuff are expected to sorb $\mathrm{Sr}$ and $\mathrm{Cs}$ significantly. To better measure sorption ratios, a higher ionic strength solution was preferred; these solutions will have a higher abundance of competing cations and for these solutions, solution/solid sorption ratios will be lower and determined with greater precision. Experimental data for batch sorption experiments using 2-mol/L, 1 $\mathrm{mol} / \mathrm{L}$ and $0.2-\mathrm{mol} / \mathrm{L} \mathrm{NaCl}-0.0035-\mathrm{mol} / \mathrm{L} \mathrm{NaHCO}_{3}$ solutions indicates a ratio near 0.5 for both the $\mathrm{Cs}$ and $\mathrm{Sr}$. Nearly identical sorption behavior for the tuff and the clinoptilolite indicates transfer dominated by ion-exchange.

Triay et al. (1991) studied the transport behavior of alkaline, alkaline-earth and transition metals ( $\mathrm{Sr}, \mathrm{Ba}, \mathrm{Cs}$ ) and actinides (Np(V), $\mathrm{Pu}(\mathrm{IV}), \mathrm{Pu}(\mathrm{VI}), \mathrm{Am}(\mathrm{III})$ ) for $99 \%$ pure silicate, alumino-silicate, carbonate, oxide and oxyhydroxide mineral separates. $\mathrm{K}_{\mathrm{d}} \mathrm{s}(\mathrm{ml} / \mathrm{g})$ determined by batch (static) sorption experiments using J-13 groundwaters equilibrated for 21 days are:

$\begin{array}{llll}\text { Mineral } & \mathrm{Sr} & \underline{\mathrm{Cs}} & \underline{\mathrm{Ba}} \\ \text { synthetic calcite } & 4.0 \times 10^{-1} & 3.3 \times 10^{-1} & 7.7 \times 10^{-1} \\ \text { calcite } & 5.7 \times 10^{\circ} & 1.3 \times 10^{0} & 5.0 \times 10^{0} \\ \text { montmorillonite } & 1.4 \times 10^{3} & 1.4 \times 10^{3} & 1.7 \times 10^{3} \\ \text { synthetic hematite } & 2.4 \times 10^{1} & 4.0 \times 10^{-2} & 1.3 \times 10^{2} \\ \text { synthetic goethite } & 1.2 \times 10^{3} & 3.1 \times 10^{0} & 1.3 \times 10^{4} \\ \text { hollandite } & 5.5 \times 10^{1} & 1.9 \times 10^{0} & 9.7 \times 10^{3} \\ \text { romanechite } & 6.2 \times 10^{1} & 6.8 \times 10^{0} & 2.2 \times 10^{4}\end{array}$


$K_{d} ' s(\mathrm{ml} / \mathrm{g})$ determined for $\mathrm{Np}(\mathrm{V})$ in pure minerals are:

$\begin{array}{lll}\text { Mineral } & \mathrm{Np} & \mathrm{Np}^{*} \\ \text { synthetic calcite } & 4.0 \times 10^{-1} & 1.2 \times 10^{1} \\ \text { calcite } & 2.4 \times 10^{2} & 6.5 \times 10^{2} \\ \text { montmorillonite } & 6.3 \times 10^{1} & 4.7 \times 10^{1} \\ \text { clinoptilolite } & & 2.7 \times 10^{1} \\ \text { synthetic hematite } & 3.3 \times 10^{3} & 3.2 \times 10^{3} \\ \text { synthetic goethite } & 1.8 \times 10^{5} & 1.1 \times 10^{5} \\ \text { hollandite } & 1.2 \times 10^{3} & 1.1 \times 10^{3} \\ \text { romanechite } & 3.8 \times 10^{2} & 3.9 \times 10^{2} \\ \text { *orption equilibration time }=21 \text { days } \\ \text { ** sorption equilibration time }=124 \text { days }\end{array}$

The experiments by Triay et al. (1991), in contrast to earlier published work, show good agreement between column and batch experiments for $\mathrm{Sr}, \mathrm{Cs}$ and $\mathrm{Ba}$ data. $\mathrm{Np}(\mathrm{V})$ sorption is driven by surface complexation. Am(III) sorption represents mechanisms of surface coprecipitation or physical adsorption and is independent of mineralogy. Pu retardation is sensitive to the oxidation potential of water. $\mathrm{Pu}(\mathrm{IV})$ exists as a colloid in J-13 groundwater. Because of its larger size $\mathrm{Pu}(\mathrm{IV})$ may not sorb and has the potential of traveling as fast or faster than the prevailing groundwater velocity. $\mathrm{Pu}(\mathrm{V})$ and $\mathrm{Pu}(\mathrm{VI})$ can act as ionic species in J-13 groundwater and maybe sorbed accordingly.

Investigations by Ticknor et al. (1991) of granitic plutons in the Canadian Shield indicate that open, water bearing fractures are a principal conduit for radionuclide migration through the geosphere. Interaction between the radionuclides in solution and the minerals in these fractures will retard radionuclide migration. These fracture-filling minerals are products of water/rock reactions and exhibit a substantively different mineralogy than that of the host rock. Ticknor et al. (1991) studied the sorptive potential of these fracture-filling minerals using batch sorption experiments coupled with autoradiography and petrography. The modal abundance of fracture filling minerals in Canadian granites is chlorite $>$ calcite $>$ hematite $>$ clay $>$ gypsum $>$ goethite $>$ pyrite $>$ quartz. Because it was not practical to obtain sufficient fracture-fill minerals from field drilled samples, pure mineral separates served as analogs in the batch sorption experiments. Synthetic groundwaters were use in the sorption experiments. For $\mathrm{Sr}$, muscovite $>$ kaolinite $>$ illite $>$ chlorite $=$ epidote $=$ goethite $=$ gypsum $=$ hematite $>$ calcite $=$ quartz. For Cs, illite $>$ kaolinite $>$ muscovite $>$ chlorite $=$ gypsum $=$ epidote $>$ calcite $=$ goethite $=$ hematite $=$ quartz. 
Sr and Cs $R_{d}$ 's $(\mathrm{ml} / \mathrm{g})$ are:

$\begin{array}{lll}\text { Mineral } & \text { Sr } & \text { Cs } \\ \text { calcite } & 0 & 0 \\ \text { chlorite } & 1 & 14 \\ \text { epidote } & 1 & 9 \\ \text { goethite } & 1 & 0 \\ \text { gypsum } & 1 & 12 \\ \text { hematite } & 1 & 0 \\ \text { illite } & 5 & 2400 \\ \text { kaolinite } & 12 & 250 \\ \text { muscovite } & 20 & 230 \\ \text { quartz } & 0 & 0\end{array}$

Sorption ratios for $\mathrm{Np}$ are consistently lower than those found for $\mathrm{U}$ or $\mathrm{Pu}$. Hematite has the highest sorption coefficient for the actinides; quartz has the lowest. In general, excluding the total dissolved solids (TDS) content or redox condition of the water, relative sorptive capacity for $U$ is hematite $=$ kaolinite $=$ goethite $=$ muscovite $=$ chlorite $>$ illite $>$ calcite $>$ gypsum $>$ quartz $>$ epidote. For $\mathrm{Np}$, hematite $=$ illite $=$ goethite $=$ calcite $=$ chlorite $>$ epidote $>$ muscovite $>$ kaolinite $=$ gypsum $\gg$ quartz. For $\mathrm{Pu}$, kaolinite $=$ illite $=$ hematite $\gg$ muscovite $=$ calcite $=$ goethite $=$ epidote $=$ chlorite $=$ gypsum $>$ quartz. Ticknor et al. (1991) note that the highest amount of Pu sorption occurred with the three minerals with the highest specific-surface area. Available surface area, rather than mineralogy, moderates the removal of $\mathrm{Pu}$ from solution. For $\mathrm{U}$ and $\mathrm{Np}$, lower specific surface area minerals, goethite, calcite and chlorite, exhibit greater sorptive capacity. For these minerals, mineralogy not surface area determines sorption. Much of the transmissivity in rocks of the Canadian Shield, like those of southern Nevada, is fracture permeability. As such, the importance of sorption by fracturefilling minerals at NTS cannot be underestimated.

Field Studies:

An experiment to measure the migration of radionuclides from a nuclear detonation was fielded at NTS. The site of the May, 19650.75 kiloton yield Cambric event, conducted in Frenchman Flat (Area 5) approximately 300 meters beneath surface in alluvium and $80 \mathrm{~m}$ beneath the water table, was re-entered ten years after the detonation. Initial results are compiled by Hoffman et al. (1977). Using packers, Hoffman et al. sampled different water masses relative to the cavity and chimney. No activity above background was found for water pumped from below the cavity. Water from the highest region of radioactivity at the cavity bottom was enriched in ${ }^{3} \mathrm{H},{ }^{85} \mathrm{Kr},{ }^{90} \mathrm{Sr},{ }^{106} \mathrm{Ru},{ }^{125} \mathrm{Sb},{ }^{137} \mathrm{Cs}$ with minor ${ }^{144} \mathrm{Ce}$ and ${ }^{239} \mathrm{Pu}$. After ten years, most of the radioactivity was still retained in melt glass in the region of the original cavity. There was no evidence that ${ }^{3} \mathrm{Kr}$ or ${ }^{3} \mathrm{H}$ had moved above the water table; $99.9 \%$ of the ${ }^{3} \mathrm{H}$ was present as $\mathrm{HTO}$. By comparing the amounts of various radionuclides produced by the Cambric device with the amounts detected in the pumped water, using ${ }^{3} \mathrm{H}$ as a reference nuclide, effective retention factors (calculated relative to the inverse of the 
radionuclide activity / tritium ratio in groundwater) for the melt glass were $10^{2}$ to $10^{4}$ for the isotopes ${ }^{90} \mathrm{Sr},{ }^{106} \mathrm{Ru},{ }^{125} \mathrm{Sb},{ }^{137} \mathrm{Cs}$ and ${ }^{144} \mathrm{Ce}$ and $>10^{6}$ for ${ }^{147} \mathrm{Pm}$ and ${ }^{239} \mathrm{Pu}$. The high values for ${ }^{147} \mathrm{Pm}$ and ${ }^{239} \mathrm{Pu}$ are likely related to a slow leach rate from the glass matrix. Higher retention values for ${ }^{90} \mathrm{Sr}$ and ${ }^{137} \mathrm{Cs}$ were found lower in the cavity region than in the chimney and imply that incorporation of radionuclides in the puddle region attenuates leaching of the radionuclides from this region and result in higher retention factors.

Results of continued studies of water pumped from the Cambric site are provided by Marsh (1992) and Bryant (1992). Over a two year interval tritium migrated from the Cambric working point to a pumped satellite well 91 meters away. Over a five year interval, tritium reached a maximum concentration in the satellite $(10 \mu \mathrm{Ci} / \mathrm{l})$ and has been decreasing since that time. $50 \%$ of the ${ }^{85} \mathrm{Kr}$ dissolved in groundwater migrated with the tritium but more slowly. Low ratios of ${ }^{85} \mathrm{Kr} /$ tritium may reflect sorption or loss of " $\mathrm{Kr}$ during transport from the cavity to the satellite well. Residual ${ }^{85} \mathrm{Kr}$ may be bound with melt glass or have escaped to the unsaturated zone. Results from the pumping experiment indicate that the only radionuclides transported to the satellite well in any significance were ${ }^{3} \mathrm{H},{ }^{106} \mathrm{Ru},{ }^{36} \mathrm{Cl}$ and ${ }^{129} \mathrm{l}$. Less than $0.5 \%$ of the total ${ }^{90} \mathrm{Sr}$ and $0.0003 \%$ of the total ${ }^{137} \mathrm{Cs}$ accompanied the tritium to the satellite well. In particular, ${ }^{129} \mathrm{Sb}$ and ${ }^{137} \mathrm{Cs}$ appear to be retarded in the alluvial aquifer at Cambric. The recharge experiments indicate that anionic radionuclides, ${ }^{36} \mathrm{Cl}$ and ${ }^{129} \mathrm{l}$, are nonconservative during unsaturated transport implying either fractionation or an external source. Comparing results of the Cambric experiment with that of a companion experiment associated with the 1167 meter deep $>200$ kiloton yield Cheshire event fired in saturated tuffs of Pahute Mesa, Buddemeier et al. (1991) conclude that I) ${ }^{3} \mathrm{H},{ }^{36} \mathrm{Cl},{ }^{129} \mathrm{I}$ and stable bromide are mutually conservative tracers in saturated ground water systems, $2{ }^{3} \mathrm{H}$ and halides do not display consistent behavior under unsaturated flow conditions, 3) ${ }^{123} \mathrm{Sb}$ and ${ }^{137} \mathrm{Cs}$ are nonconservative and capable of substantial migration in fractured tuff, 4) cavity-chimney systems can be treated as a homogeneous hydrologic source term and initial source term chemical inhomogeneities become insignificant as time and hydrologic transport progresses.

Buddemeier and Hunt (1988) report on sorption of radionuclides by colloids and their transport in NTS groundwaters. Using waters were collected by pumping from a re-entry hole drilled into the Cheshire cavity and subsequently filtered. Selected filtered samples were ultrafiltered through 100,000 or 10,000 MWU cassette ultrafilters (nominal pore sizes 0.006 and $0.003 \mu \mathrm{m}$ respectively). The filtrates and retentates were then counted by gamma spectroscopy. Cavity waters varied in TDS between 265 and 260 ppm; formation waters had slightly lower TDS levels ranging between 217 and $219 \mathrm{ppm}$. Colloidal mass concentrations ranged between 25 and $65 \mathrm{ppm}$ for the cavity waters and ranged between 4.3 to $4.6 \mathrm{ppm}$ for the formation waters. Colloids ranged in size between 0.003 and $0.45 \mu \mathrm{m}$. Colloidal material in the size range of 0.20 and $0.006 \mu \mathrm{m}$ contained a significant fraction of the total activity of the radionuclides $\mathrm{Mn}, \mathrm{Co}, \mathrm{Cs}, \mathrm{Ce}$ and $\mathrm{Eu}$. Buddemeier and Hunt note that different radioisotopes of the same element have different parents and different production mechanisms (fission versus activation). As such, comparison of isotopes is diagnostic of the degree of geochemical equilibrium in the cavity. Their data indicate that the isotopes of $\mathrm{Cs}$ and $\mathrm{Eu}$ vary only slightly in total activity. Since these isotopes represent either activation products, 
fission products with a volatile precursor or fission products with a refractory precursor, sorption occurs on a time scale short relative to the time elapsed since detonation.

Fractionation associated with the explosion is of minor importance relative to long term hydrologic transport. $\mathrm{X}$-ray diffraction indicates the colloidal phases (retentate) are dominated by $\mathrm{Ca}-\mathrm{K}$ feldspars and fine clays. Adsorption and desorption of radioniclides can be quantified for nuclides that can be detected in the filtrate fraction and for the $0.05-0.003 \mu \mathrm{m}$ colloidal retentates. Calculated $K_{d}$ 's $(\mathrm{ml} / \mathrm{g})$ for cavity colloids are $1.1 \times 10^{5}$ for ${ }^{106} \mathrm{Ru}, 1.3 \times$ $10^{3}$ for ${ }^{123} \mathrm{Sb}, 7.6 \times 10^{3}$ for ${ }^{134} \mathrm{Cs}$ and $10.1 \times 10^{3}$ for ${ }^{137} \mathrm{Cs}$. Values for formation waters are 1.7 $\times 10^{5}$ for ${ }^{106} \mathrm{Ru}, 1.3 \times 10^{3}$ for ${ }^{125} \mathrm{Sb}, 5.3 \times 10^{3}$ for ${ }^{134} \mathrm{Cs}$ and $8.7 \times 10^{3}$ for ${ }^{137} \mathrm{Cs}$. Buddemeier and Hunt caution that any procedure, during pumping, sampling, filtration or characterization, which alters colloid sizes would give results that could not be used for quantitative prediction of transport. Nonetheless, they offer the following conclusions:

- Colloidal particles sorb radionuclides, particularly in the case of elements that are strongly sorbing and/or insoluble in groundwaters.

- Both dissolved and colloidal radionuclides undergo hydrologic transport through a fracture flow system.

- Colloids are finer than the $0.45 \mu \mathrm{m}$ "break" traditionally used to distinguish particulate and dissolved species.

- Colloids are composed of quartz, feldspars and clays. High colloid concentrations are not unique to the Cheshire study site and may be representative of groundwaters at NTS.

- Radionuclides have equilibrated with groundwaters and their behavior is representative of the trace element geochemistry of these waters.

- Colloidally sorbed radionuclides are transported less efficiently than soluble neutral or anionic species. Colloids and cations experience additional exchange with the aquifer during hydrologic transport.

\section{SUMMARY OF SORPTION AND DESORPTION OF RADIONUCLIDES}

Parameters directly affecting sorption include: groundwater composition, the abundance, composition and cation exchange capacity of minerals comprising the host lithology and the temperature, oxidation state and specific radionuclide in solution (Ogard, 1984). To determine sorption coefficients three different experiments have been devised. Batch sorption experiments approximate equilibrium distribution coefficients for long-term experiments and yield data on chemical kinetics in short-term experiments. Agitation of the solution can also produce extremely fine particles due to self grinding of the crushed rock bed. "Equilibrium" sorption coefficients from batch experiments may not be representative of a flowing system. Crushed rock flow-through column experiments eliminate the problems of batch experiments but exclude particles finer than $38 \mu \mathrm{m}$. Circulating experiments are essentially batch experiments where the liquid is multiply passed over the stationary solid phase. Circulating systems eliminate the fine self grinding which affect batch experiments. Specific summary points follow: 
- For NTS tuffs and volcaniclastic alluvium, sorption coefficients increase as follows: $\mathrm{Sb}<\mathrm{Sr}<\mathrm{U}<\mathrm{I}<\mathrm{Ru}<\mathrm{Nb}<\mathrm{Ba}<\mathrm{Cs}<\mathrm{Co}<\mathrm{Y}<\mathrm{Ce}<\mathrm{Eu}$. In relative terms, $\mathrm{R}_{\mathrm{d}}$ 's are arranged as: $\mathrm{Pu}>\mathrm{Cs}$; $\mathrm{Cs}>\mathrm{Sr}, \mathrm{Sr}>\mathrm{Tc}$. For actinides, $\mathrm{R}_{\mathrm{d}}$ 's can be arranged $\mathrm{Th}>\mathrm{Pu}>\mathrm{Am}>\mathrm{Np}>\mathrm{Ra}$.

- Sorption coefficients derived from the batch and flow-through experiments of Treher and Raybold (1982) and Triay (1991) are similar for particles $>38 \mu \mathrm{m}$; in contrast for particles $<38 \mu \mathrm{m}$, Vine et al. (1980), Daniels (1981) and Treher and Raybold (1982) find sorption coefficients determined from batch experiments are higher than those from flow-through experiments. Sorption coefficients determined from circulating fluid experiments approximate those from flow-through experiments.

- Sorption is moderated by the conic size, electronegativity, oxidation state and solubility of a specific radionuclide. Large ionic size and complexity (ability to form anions) attenuate sorptive capacity; if the oxidation state favors strongly ionic species, ion exchange reactions are enhanced. Whether a radionuclide is in solution will affect whether it is transported as a colloid at a potentially faster velocity than prevailing groundwater.

- Particle size influences sorption measurements. A decrease in particle size will cause an increase in $K_{d}$. However, data from batch experiments indicate that particle size has little effect on retardation over the size range of 100 to $500 \mu \mathrm{m}$.

- Changes in $\mathrm{pH}$ and fluid composition affect sorption. $\mathrm{H}^{+}$may act as another cation in solution or may shift equilibrium conditio $s$. The more concentrated the solution with major cations and anions, sorption for $\mathrm{Cs}$ and $\mathrm{Ba}$ will be higher and sorption for $\mathrm{Eu}$ will be lower. In dilute water, with few competing cations, radionuclides are effectively removed from solution and measured $K_{d}$ 's are very large. In more concentrated solutions, assuming ion-exchange dominates sorption, there ia a higher abundance of competing cations and sorption ratios for a given radionuclide will be lower.

- An increase in solution/solid ratios from 5:1 to 30:1 increases the sorption of $\mathrm{Ba}, \mathrm{Ce}$ and $\mathrm{Eu}$ by a factor of $\mathrm{S}$ in tuff. Precipitation and/or sorption drives these changes. Sorption of $\mathrm{Cs}$ and $\mathrm{Sr}$ is not affected.

- Mineralogy controls sorption. Clays and zeolites, abundant in NTS tuffs and alluvial sediments, display strong ion-exchange behavior which dominates sorption in these rocks. Studies with pure mineral separates indicate for the relative sorption of $\mathrm{Sr}, \mathrm{Cs}, \mathrm{Ba}, \mathrm{U}, \mathrm{Np}$ that goethite $>$ montmorillonite $>$ calcite $>$ quartz. Since fluid transport is faster in fractures relative to intergranular (matrix) flow or diffusion, the importance of identifying sorbing fracture lining minerals must not be underestimated. 
- Laboratory studies validate field investigations of radionuclide retardation associated with underground nuclear tests. The Cambric and Cheshire nuclear events indicate ${ }^{3} \mathrm{H},{ }^{106} \mathrm{Ru},{ }^{36} \mathrm{Cl}$ and ${ }^{129} \mathrm{I}$ migrate away from nuclear cavities and are conservative tracers of fully saturated groundwater flow. Retardation for $\mathrm{Sr}, \mathrm{Ru}, \mathrm{Sb}$, $\mathrm{Cs}$ and $\mathrm{Ce}$ is two orders of magnitude less than for $\mathrm{Pm}$ and $\mathrm{Pu} .{ }^{125} \mathrm{Sb}$ and ${ }^{137} \mathrm{Cs}$ are capable of substantive migration through fractures in tuff relative to transport in alluvium. ${ }^{3} \mathrm{H}$ and halides $\left({ }^{36} \mathrm{Cl},{ }^{129} \mathrm{l}\right)$ display inconsistent transport behavior under unsaturated flow conditions.

- Colloids sorb radionuclides. Calculated $\mathrm{K}_{d} \mathrm{~s}(\mathrm{ml} / \mathrm{g})$ for cavity colloids are $1.1 \mathrm{x}$ $10^{5}$ for ${ }^{106} \mathrm{Ru}, 10.1 \times 10^{3}$ for ${ }^{137} \mathrm{Cs}$, $7.6 \times 10^{3}$ for ${ }^{134} \mathrm{Cs}$ and $1.3 \times 10^{3}$ for ${ }^{125} \mathrm{Sb}$. Most NTS colloids are quartz, feldspar and clays and are transported less efficiently than soluble neutral or anionic species.

\section{SUMMARY AND SUGGESTIONS FOR FUTURE WORK}

This review of the subject of sorption and leachi ig of radionuclides from nuclear melt glass has tried to provide a representative summary of pertinent work completed to-date.

The following are the general conclusions drawn from this review:

- Phenomenology must be understood in the context of the development, distribution, composition and texture of melt glasses as these parameters will significantly affect subsequent leaching and sorption. The shock wave accompanying the detonation vaporizes 70 metric tons and melts 700 metric tons of rock for every kiloton of nuclear explosive yield. The glasses are extremely heterogeneous in major element composition and the silica content and alkali/Si ratio will substantively affect how refractory these matrices are in the presence of groundwaters. The setting of these glasses is further complicated by the structure of the cavity and chimney. Cavity wall blocks fall into the puddle of melt glass at the cavity bottom which is further disaggregated during subsequent chimney collapse. Beyond the fused margins of the cavity a crush zone of highly pulverized rock presents a higher permeability aureole surrounding the working point.

- Differential condensation processes fractionate the near-field distribution of radionuclides following a nuclear explosion. Refractory radionuclides whose melting points exceed that of the surrounding geologic media are contained in the puddle region. $65-80 \%$ of the fission products become incorporated in the melt. Radioactive cavity gasses migrate through the strongly shocked and crushed rubble and the radioisotopes of intermediate volatility complete their condensation. These nuclides are surface-deposited rather than volume incorporated. Condensation occurs as cavity gasses ascend upwards toward the ground surface. Volatile species are enriched in the upper part of the chimney; condensation occurs on non-molten particles and may lead to the surface deposition of radionuclides. As such, the distribution of radionuclides is fractionated with the more refractory radionuclides being concentrated within the glass and the more volatile radionuclides ascending towards the 
surface where they adhere ultimately in the soil column. As a result of this distribution, groundwater leaching (matrix effects) will prevail at depth and sorption (surface effects) will dominate at shallower intervals. Tritium poses a threat to ground water contamination because, as HTO, it is a water molecule and will behave exactly as the groundwater itself.

- In general, leaching rates are uniform for radionuclides dissociated from nuclear melt glass; deviations from uniformity are due to alteration of the glass and resulting sorption. Without considering sorption over geologic time, averages for the leaching rate (in fraction leached per day) of high-grade, non-high-grade, ground and bulk melt glass debris samples from Yucca Flat and Pahute Mesa are arranged in decreasing order: ${ }^{131} I$ (leaching rate: $0.9 \mathrm{E}^{.3}$ ) $>{ }^{129,132} \mathrm{Te}>{ }^{181,188} \mathrm{~W}>{ }^{124,127} \mathrm{Sb}>{ }^{137} \mathrm{Cs}>{ }^{237} \mathrm{U}>{ }^{88,60} \mathrm{Co}>{ }^{103,106} \mathrm{Ru}>{ }^{182} \mathrm{Ta}>{ }^{140} \mathrm{Ba}>{ }^{141,144} \mathrm{Ce}>$ ${ }^{34} \mathrm{Mn}>{ }^{88} \mathrm{Y}>{ }^{95} \mathrm{Zr}>{ }^{219,240} \mathrm{Pu}$ (leaching rate: $3 \mathrm{E}^{\cdot 7}$ ). For a majority of radionuclides studied, less than $1 \%$ of their initial activity is released during leaching experiments; only Sb exceeded $3 \%$ of the initial activity leached. The kinetics of the leaching implies the release of radionuclides occurs by a process more complex than simple dissolution.

- Sorption coefficients determined from static and dynamic experiments increase as follows: $\mathrm{Sb}<\mathrm{Sr}<\mathrm{U}<\mathrm{I}<\mathrm{Ru}<\mathrm{Nb}<\mathrm{Ba}<\mathrm{Cs}<\mathrm{Co}<\mathrm{Y}<\mathrm{Ce}<\mathrm{Eu}$. In relative terms, $\mathrm{R}_{\mathrm{d}}$ 's are arranged as: $\mathrm{Pu}>\mathrm{Cs}$; $\mathrm{Cs}>\mathrm{Sr} ; \mathrm{Sr}>\mathrm{Tc}$. For actinides, retardation factors can be arranged $\mathrm{Th}>\mathrm{Pu}>\mathrm{Am}>\mathrm{Np}>\mathrm{Ra}$. Mineralogy dominates sorptive capacity. Clays $: 11$ zeolites, abundant in NTS tuffs and alluvium, display strong ion-exchange behavior which controls sorption in these rocks. Studies of pure mineral separates indicate for the relative sorption of $\mathrm{Sr}, \mathrm{Cs}, \mathrm{Ba}, \mathrm{U}$ and $\mathrm{Np}$, goethite $>$ montmorillonite $>$ calcite $>$ quartz. Laboratory studies validate field investigations of radionuclide migration associated with underground nuclear tests. Studies of the 0.75 kiloton yield Cambric and the $>200$ kiloton yield Cheshire nuclear events indicate ${ }^{3} \mathrm{H},{ }^{106} \mathrm{Ru},{ }^{36} \mathrm{Cl}$ and ${ }^{129} \mathrm{I}$ migrate away from nuclear cavities and are conservative tracers of groundwater flow. Retardation for $\mathrm{Sr}, \mathrm{Ru}, \mathrm{Sb}, \mathrm{Cs}$ and $\mathrm{Ce}$ is two orders of magnitude less than for $\mathrm{Pm}$ and $\mathrm{Pu}$. As well, colloids sorb radionuclides. A majority of NTS colloids are quartz, feldspar and clays which are transported less efficiently than soluble neutral or anionic radionuclides.

- It is recommended that, although radionuclides pose only a small threat to NTS ground waters, the exchange between glass and water warrants better characterization. The melt glass itself is extremely heterogeneous and requires both compositional and textural characterization. In particular, the composition of the glass will determine how susceptible it is to leaching. Further study of the distribution of radioactivity in the glass is important as are further studies of glass alteration products. For example, do clay-rich surfaces develop at the alteration front and, if so, do these "rinds" remain or do they separate from the glass matrix? The presence of secondary minerals, if any, that form on these alteration surfaces will influence the sorption of radionuclides. Much of what is known about leaching (and sorption) of radionuclides from nuclear debris was published over ten years ago; the number of nuclear tests and access to device debris has diminished during the subsequent decade. Nonetheless, NTS groundwater characterization and remediation efforts demand that experimental work continue. Integrated melt glass characterization and leaching studies will 
emphasize heterogeneities in glass texture and composition and its effect on the mechanism and rate of glass dissolution. Leaching of melt glass as a function of temperature warrants investigation; solubility and leaching rate may be affected by elevated temperatures resident long after detonation.

\section{ACKNOWLEDGEMENTS}

This report was sponsored by the Hydrologic Resources Management Program of the DOE Nevada Operations Office (DOE-NVOO). Thorough and insightful reviews by Greg Nimz and Ken Marsh of the Nuclear Chemistry Division and Bill Bourcier of the Earth Sciences Department at LLNL helped clarify my thinking on this subject as well greatly improve the organization of the manuscript. Chuck Smith, Nuclear Chemistry Division Program Leader for Nuclear Test, provided valuable input on nuclear test phenomenology as well as read this report as authorized derivative classifier. Sue DeWitt and Hazel Burris assisted in production and duplication of this document. Most of the referenced reports were provided by the Reports Library of the Technical Information Department (TID) at LLNL. 


\section{REFERENCES CITED}

Borg, I.Y., R. Stone, H.B. Levy, L.D. Ramspott, 1976, Information pertinent to the migration of radionuclides in ground water at the Nevada Test Site, Part 1: review and analysis of existing information, Lawrence Livermore National Laboratory, UCRL-52078, Pt. 1, $216 \mathrm{p}$.

Borg, I.Y., R. Stone, H.B. Levy, L.D. Ramspott, 1976, Information pertinent to the migration of radionuclides in ground water at the Nevada Test Site, Part 2: annotated bibliography, Lawrence Livermore National Laboratory, UCRL-52078, Pt. 2, 112p.

Bryant, E.A., 1992, The Cambric migration experiment - a summary report, Los Alamos National Laboratory, LA-12335-MS, 37p.

Buddemeier, R.W. and J.R. Hunt, 1988, Transport of colloidal contaminants in groundwater: radionuclide migration at the Nevada Test Site, Applied Geochemistry, v. 3, p. 535548.

Buddemeier, R.W., R.C. Finkel, K.V. Marsh, M.R. Ruggieri, J.H. Rego and R.J. Silva, 1991, Hydrology and Radionuclide Migration at the Nevada Test Site, Radiochimica Acta, v. $52 / 53$, p. $275-282$.

Butkovich, T.R., 1970, The influence of water in rocks on underground nuclear explosions effects, Lawrence Livermore National Laboratory, UCRL-72558, Preprint, 20p.

Daniels, W.R., 1981, Laboratory studies of radionuclide distributions between selected groundwaters and geologic media, October 1, 1979 - September 30, 1980, Los Alamos National Laboratory, LA-8586-PR, 72p.

Erdal, B.R., 1979, Laboratory studies of radionuclide distributions between selected groundwaters and geologic media, April 1 - June 30, 1979, Los Alamos National Laboratory, LA-7893-PR, 53p.

Erdal, B.R., 1980, Laboratory studies of radionuclide distributions between selected griundwaters and geologic media, April 1 - June 30, 1980, Los Alamos National Laboratory, LA-8472-PR, 28p.

Essington. E.H. and J.V.A. Sharp, 1968, Some aspects of ground-water solution chemistry, unclerground nuclear explosion zones, Nevada Test Site, in Nevada Test Site, E.B. Eckel, ed., Geological Society of America, Memoir 110, pg. 263 - 273.

Essington, E.H., 1971, Long term release of radioactivity from Rainier melt-glass, Teledyne Isotopes for U.S. Atomic Energy Commission, Nevada Operations Office, NVO-1229$177,12 \mathrm{p}$. 
Failor, R.A., D.G. Coles, J.H. Rego, 1983, A leaching study of nuclear melt glass: part I, Lawrence Livermore National Laboratory, UCID-19729, 71p.

Higgins, G.H., 1959, Evaluation of the ground water contamination hazard from underground nuclear explosions, Jour. Geophys. Research, v. 64, pg. $1509-1519$.

Hoffman, D.C., R. Stone and W.D. Dudley, 1977, Radioactivity in the underground environment of the Cambric nuclear explosion at the Nevada Test Site, Los Alamos, National Laboratory, LA-6877-MS, 89p.

Isherwood, D., 1977, Preliminary report on retardation factors and radionuclide migration, Lawrence Livermore National Laboratory, UCID-17551, 22p.

Knox, J.B., 1968, Water quality in flooded nuclear craters, Lawrence Livermore National Laboratory, UCRL-50531, 23p.

MacLean, S.C., D.G. Coles, H. C. Weed, 1978, The measurement of sorption ratios for selected radionuclides on various geologic media, Lawrence Livermore National Laboratory, UCID-17928, 25p.

Marsh, K.V., 1992, Hydrology and radionuclide migration program 1989 progress report, Lawrence Livermore National Laboratory, UCRL-53779-89, 25p.

Meyer, R.E., W.D. Arnold, F.I. Case, G.D. O'Kelley and J.F. Land, 1991, Effects of mineralogy on the sorption of strontium and cesium on Calico Hills tuff, Scientific Basis for Nuclear Waste Management XIV, Materials Research Society Symposium Proceedings, v. 212, p. 569-576.

Morey, G.W., 1958, The action of heat and superheated steam on the tuff of the Oak Spring Formation, U.S. Geological Survey, Trace Elements Investigations Report 729, 13p.

Ogard, A.E., K. Wolfberg, W.R. Daniels, J. Kerrisk, R.S. Rundberg and K.W. Thomas, 1984, Retardation of radionuclides by rock units along the path to the accessible environment, Scientific Basis for Nuclear Waste Management VII, Materials Research Society Symposium Proceedings, v. 26, p. 329-336.

Ramspott, L.D., J.D. Tewhey, D.G. Coles, H.C. Weed, J.S. Schweiger, R. Stone, 1979, FY78 annual technical report of Lawrence Livermore Laboratory's participation in the DOENV project: radionuclide migration in the ground, Lawrence Livermore National Laboratory, UCID-18259-78, 29p.

Schwartz, L., A. Piwinskii, F. Ryerson, T.Tewes, and W. Beiriger, 1984, Glass produced by underground nuclear explosions, in Natural Glasses, L.D. Pyle, J.A. O'Keefe, and V.D. Frechette eds., Amsterdam, North Holland, pg. 559-591. 
Shore, B., L. Anspaugh, R. Chertok, J. Gofman, F. Harrison, R. Heft, J. Koranda, Y. Ng, P. Phelps, G. Potter, A. Tamplin, 1969, The fate and importance of radionuclides produced in Plowshare events, Lawrence Livermore National Laboratory, UCRL 71443, Preprint, 45p.

Ticknor, K.V., D.C. Kamineni and T.T. Vandergraaf, 1991, Flow path mineralogy: its effect on radionuclide retardation in the geosphere, Scientific Basis for Nuclear Waste Management XIV, Materials Research Society Symposium Proceedings, v. 212, p. 661-668.

Treher, E.N. and N.A. Raybold, 1982, The elution of radionuclides through columns of crushed rock from the Nevada Test Site, Los Alamos National Laboratory, LA-9329 - MS, 134p.

Triay, I.R., A.J. Mitchell and M.A. Ott, 1991, Radionuclide migration as a function of mineralogy, High Level Radioactive Waste Management, Proceedings of the Second International Conference, American Nuclear Society and American Society of Civil Engineers, p. 494-498.

Wadman, R.E. and W.D. Richards, 1961, Postshot geologic studies of the excavations below Rainier ground zero, Lawrence Radiation Laboratory - Livermore Site, UCRL-6586, $31 \mathrm{p}$.

Wilmarth, V.R., 1959, Some effects of underground nuclear explosions on tuff, U.S. Geological Survey, Trace Elements Investigations Report 756, 34p.

Wolfsberg, K., 1978, Sorption-desorption studies of Nevada Test Site alluvium and leaching studies of nuclear test debris, Los Alamos National Laboratory, LA-7216-MS, 32p.

Wolfberg, K., R.D. Aguilar, B.P. Bayhurst, W.R. Daniels, S.J. DeVilliers, B.R. Erdal, F.O. Lawrence, S. Maestas, A.J. Mitchell, P.Q. Oliver, N.A. Raybold, R.S. Rundberg, J.L. Thompson and E.N. Vine, 1981, Sorption-desorption studies on tuff: III. A continuation of studies with samples from Jackass Flats and Yucca Mountain, Nevada, Los Alamos National Laboratory, LA-8747-MS, 66p.

Vine, E.N., B.P. Bayhurst, W.R. Daniels, S.J. DeVilliers, B.R. Erdal, F.O. Lawrence and K. Wolfsberg, 1980, Radionuclide transport and retardation in tuff, Scientific Basis for Nuclear Waste Management, Materials Research Society Symposium Proceedings, v. 3, p. 483-490. 

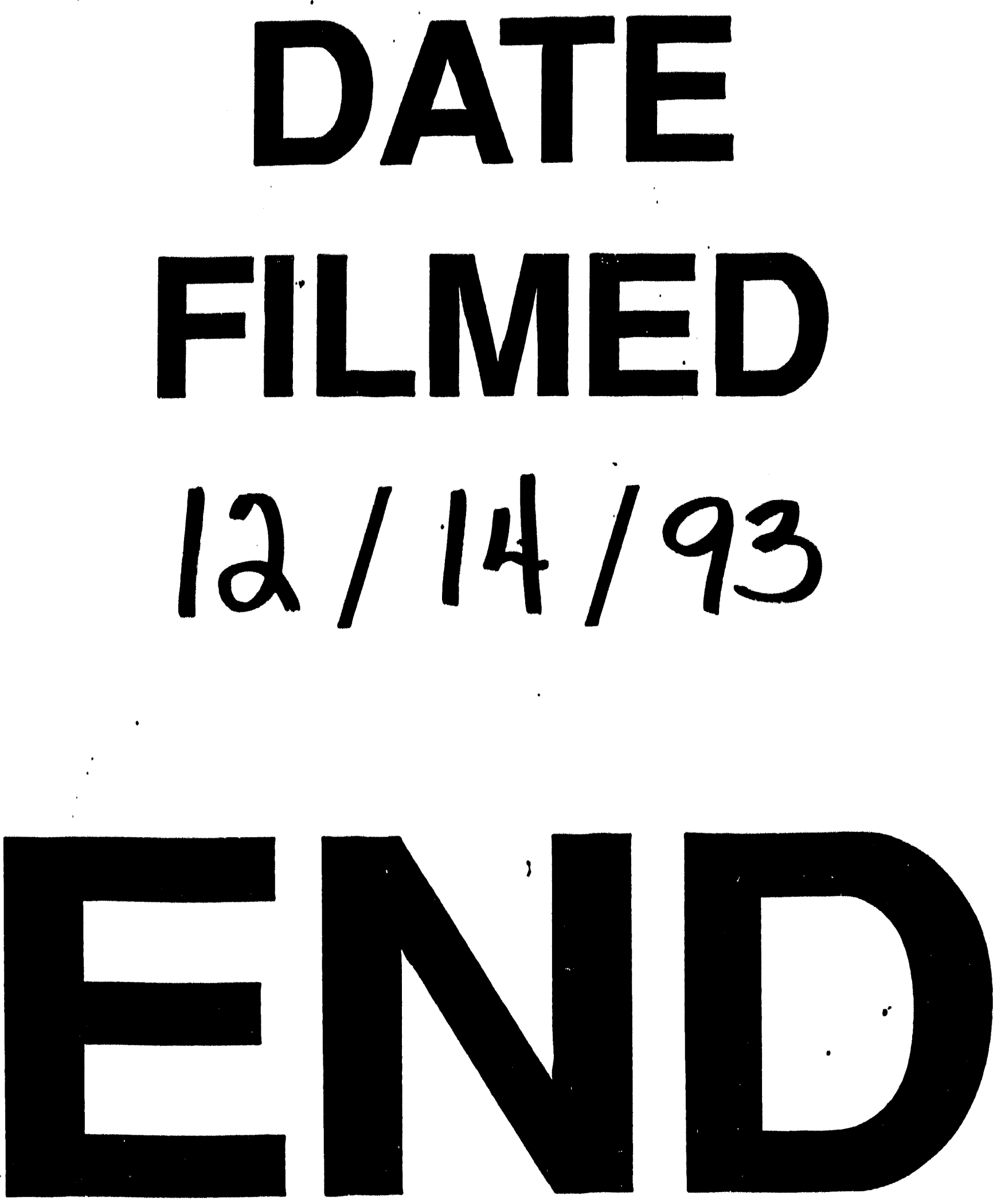
